\title{
Maternal and neonatal outcome in pre-eclamptic mothers with elevated liver enzymes: A prospective analytical study
}

\author{
Puneeta Mahajan $^{1}$, Vinita Gupta ${ }^{2}$, Aarushi Chaudhary ${ }^{3, *}$, Shinky Mehta ${ }^{4}$ \\ ${ }^{1}$ Medical Director, ${ }^{2} \mathrm{OBG}$ Specialist, ${ }^{3}$ Secondary DNB Resident, ${ }^{4}$ Senior Resident, ${ }^{1-3}$ Dept. of Obstetrics and Gynaecology, ${ }^{4}$ Dept. \\ of Biochemistry, Dr. Baba Saheb Ambedkar Medical College and Hospital, Rohini, New Delhi, India
}

*Corresponding Author:

Email: prof.aarushi@gmail.com

\begin{abstract}
Introduction: Hypertensive disorders during pregnancy may cause damage to liver which may manifest biochemically as a deranged liver function test and subsequent maternal morbidity and mortality any elevation in liver enzymes in a pre-eclamptic patient is significant and influences fetomaternal outcome this study evaluates the liver enzymes as a diagnostic and therapeutic tool in the management of preeclampsia and establishes a correlation between severity of liver function test derangement and severity of fetomaternal complications and use it as a predictive tool of severity of preeclampsia and for termination of pregnancy.

Aim was to evaluate maternal and neonatal outcome in pre-eclamptic mothers with and without transaminitis.

Primary objective of the study was to compare the maternal and neonatal outcome in pregnant women with preeclampsia in singleton pregnancies with gestational age $>24$ weeks with and without transaminitis.

Secondary objective was to correlate the severity of liver enzyme derangement in preeclamptic mothers with adverse maternal and / or fetal outcome and use it as a predictive tool of severity of preeclampsia and for termination of pregnancy

Materials and Methods: This prospective cohort study was conducted on 281 patients after approval by the institute ethics committee informed consents were taken from patients inclusion and exclusion criteria were met all enrolled patients were classified into mild, moderate and severe hypertension and managed as per standard guidelines. Specific investigations were performed if during any visit ast $>25 \mathrm{iu} / \mathrm{l}$ and/or alt $>32 \mathrm{iu} / \mathrm{l}$ and/or alp $>418 \mathrm{iu} / \mathrm{l}$, patients were called again after a week and blood pressure and fetomaternal well-being was assessed termination of pregnancy was done as per standard guideline statistical analysis done and hypothesis established.

Results: From the present study it can be derived that at ast $>66 \mathrm{iu} / \mathrm{l}$ and alt $>64 \mathrm{iu} / \mathrm{l}$ poor maternal outcome is expected with ast $>60 \mathrm{iu} / \mathrm{l}$ and alt>64 iu/l adverse fetal complications are likely to occur.

Conclusion: From the present study it can be concluded that severity of liver function test derangement is directly related to severity of preeclampsia which in turn is related to severity of fetomaternal complications.
\end{abstract}

Keywords: Elevated liver enzymes, Preeclampsia, Maternal, Neonatal outcome.

\section{Introduction}

Hypertensive disorders are common medical problems encountered during pregnancy with reported incidence between $5-10 \% .^{1}$ They form one of the deadly triad along with haemorrhage and infection contributing to maternal and fetal morbidity and mortality. ${ }^{1-4}$ Altered biochemical markers signify changes in the body which become intensified in the presence of some pathology like hypertension, diabetes, cardiac and renal disease. The severity of changes is related to the severity of pathology. There is no significant change in liver size during a normal pregnancy, however hepatic arterial and portal venous blood flow increase substantially. ${ }^{6}$ Alterations in the liver enzymes are also minimal. The aminotransferases (AST and ALT), gamma glutamyl transpeptidase (GGT), total bilirubin, and serum bile acid level remain almost same as non-pregnant value. The only significant change observed is doubling of total alkaline phosphatase which is mainly placental in origin, that to near third trimester. The albumin level is lower as compared to nonpregnant women and the cholesterol level higher. ${ }^{7}$ So, any elevation in aminotransferases or gamma GGT signifies some pathology and should prompt a search for disease. ${ }^{5}$

Alanine transaminase levels between 2 and $25 \mathrm{U} / \mathrm{L}$ and aspartate transaminase levels between 4 and $32 \mathrm{U} / \mathrm{L}$ are taken as normal during pregnancy. ${ }^{8-11}$ ALP values ranging between 130 and $418 \mathrm{U} / \mathrm{L}$ are also considered normal during antenatal period. ${ }^{12,13}$ Whenever the values are outside this range, it signifies derangement of liver function which can have multiple causes.

Although there is evidence to prove that severity of liver function test derangement is directly related to severity of preeclampsia which in turn is related to severity of fetomaternal complications but it has not been used as a diagnostic and therapeutic tool in classification and management of preeclampsia. Blood pressure and urine albumin are used as denominators for management and termination strategies till now.

Also as definitive management of preeclampsia is termination of pregnancy with ultimate aim of achieving optimal fetomaternal well-being therefore an attempt is being made to evaluate the liver enzymes as a diagnostic and therapeutic tool in the management of preeclampsia and to establish a correlation between 
severity of liver function test derangement and severity of fetomaternal complications.

\section{Aims and Objectives}

Aim of the study was to evaluate maternal and neonatal outcome in pre-eclamptic mothers with and without transaminitis.

Primary objective of the study was to compare the maternal and neonatal outcome in pregnant women with preeclampsia in singleton pregnancies with gestational age >24 weeks with and without transaminitis.

Secondary objective was to correlate the severity of liver enzyme derangement in preeclamptic mothers with adverse maternal and/or fetal outcome and use it as a predictive tool of severity of preeclampsia and for termination of pregnancy.

\section{Materials and Methods}

This prospective cohort study was conducted in the department of Obstetrics and Gynaecology at a tertiary care level hospital between September 2016 to June 2017. The study was approved by the Institute Ethics Committee and informed consents were taken from patients before inclusion in the study.

\section{Study Population}

Inclusion Criteria: All preeclamptic women with gestational age $>24$ weeks with singleton pregnancy and an elevated liver enzymes were included as cases, whereas those without an elevated liver enzymes were included as controls.

Exclusion Criteria: Twin pregnancy, antepartum hemorrhage, preterm onset of labour, rhesus negative pregnancy, intrahepatic cholestasis of pregnancy, acute fatty liver of pregnancy, viral hepatitis, liver cirrhosis, portal hypertension with esophageal varices, hemochromatosis, wilson's disease, congenital liver disease, autoimmune hepatitis, hepatic adenomas, hepatocellular carcinomas, non-alcoholic fatty liver disease. Mothers with any systemic illnesses were also excluded.

Clinical Data: Detailed baseline information of maternal and neonatal variables were recorded in a predesigned proforma including age of mother, socioeconomic status, number of antenatal visits (booked pregnancy was defined as $\geq 4$ and unbooked as $<4$ antenatal visits), gestational age at delivery, maternal medical and reproductive history, mode of delivery, still birth, Apgar scores at 1 and $5 \mathrm{~min}$, meconium staining of liquor and duration of NICU stay. Weight of the newborn was recorded immediately after delivery in an electronic weighing scale with an accuracy within $5 \mathrm{~g}$.

IUGR status was defined as discrepancy between gestational age assessment by clinical examination and antenatal scans of $>3$ weeks and/or estimated fetal weight $<10$ th centile as per standards using antenatal scan.

Maternal complications in the form of severity of Preeclampsia, eclampsia, HELLP syndrome, Placental abruption, intensive care admission and duration of stay, requirement of transfusion, hepatic failure [Hepatic Encephalopathy with deranged INR], renal failure, postpartum haemorrhage, PRES syndrome, fetal distress, requirement of magnesium Sulfate Prophylaxis were also recorded

All enrolled patients were classified into mild, moderate and severe hypertension and managed as per RCOG guideline. ${ }^{14}$ Specific investigations were performed including a complete blood count, liver function tests (LFT), renal function tests and prothrombin time. Fundus examination was also done.

Clinical assessment was done during each visit and LFT was repeated at every two weeks interval. If during any visit AST >25 IU/l and/or ALT >32IU/L and/or ALP > $418 \mathrm{IU} / \mathrm{L}$, patients were called again after a week and blood pressure and fetomaternal well-being was assessed. Termination of pregnancy was done as per the RCOG guideline. ${ }^{14}$ LFT was repeated within 48 hours of delivery and compared with the previous values.

Statistical analysis: Using a prevalence rate of transaminitis of $24 \%$ amongst preeclamptic mothers based upon a previous study with an alpha error of 5\% and a $5 \%$ margin of error the minimum required sample size was 281 patients. Categorical variables were represented as numbers and percentages (\%) and continuous variables as mean and SD or median with IQR. Normality of data was tested by KolmogorovSmirnov test. Unpaired t-test/Mann-Whitney U Test were used to compare between two different groups and paired $\mathrm{T}$ test/Wilcoxon rank sum test was used to compare across follow up. Qualitative variables were correlated using Chi-Square test /Fisher's exact test as applicable. Pearson correlation coefficient/Spearsman rank correlation coefficient was used to assess the correlation between the variables as applicable. Receiver operating characteristic curve was used to find out the cut off point of BP and liver enzymes for predicting maternal and fetal complications. A $\mathrm{p}$ value of $<0.05$ has been considered statistically significant.

\section{Results}

The data in table 1 and 2 shows maternal and fetalneonatal complications of the study subjects. It shows that $90 \%$ of patients had a normal vaginal delivery, $11.74 \%$ received magnesium sulphate prophylaxis, $3.56 \%$ had abruption, $3.20 \%$ had eclampsia, $1.42 \%$ developed HELLP syndrome, $0.71 \%$ developed DIC, PE, ARF and $0.36 \%$ patients died. Also, $7.11 \%$ developed FGR, FD noted in $3.20 \%$ patients, $3.56 \%$ developed MSL, $1.07 \%$ had an IUD and NICU stay noted in $12.09 \%$ babies. 
The data in table 3 shows comparison of liver enzymes at inclusion and derangement. It shows that there is significant elevation in the levels of SGOT, SGPT and ALP at the time of derangement.

The data in table 4 shows correlation between liver enzymes and blood pressure. It shows that systolic and diastolic blood pressure both at admission/derangement are directly correlated with liver enzymes (SGOT, SGPT).

The data in table 5 shows sensitivity, specificity of liver enzymes for maternal complications. It shows that at $66 \mathrm{IU} / \mathrm{L}$ aspartate aminotransferase is $88 \%$ specific and $90 \%$ sensitive for predicting maternal complications in preeclamptic patients with deranged liver enzymes. Alanine aminotransferase at $64 \mathrm{IU} / \mathrm{L}$ is $88 \%$ sensitive and $90 \%$ specific for same.

The data in table 6 shows sensitivity, specificity of liver enzymes for fetal complications. It shows that at $60 \mathrm{IU} / \mathrm{L}$ aspartate aminotransferase is $94 \%$ sensitive and $92 \%$ specific for predicting fetal complications in preeclamptic patients with deranged liver enzymes. Alanine aminotransferase at $64 \mathrm{IU} / \mathrm{L}$ is $94 \%$ sensitive and $92 \%$ specific for same.

Table 1: Maternal complications at a glance

\begin{tabular}{|c|l|c|c|}
\hline Maternal Complications & & Frequency & Percentage \\
\hline Mode of delivery & Hysterotomy & 1 & $0.36 \%$ \\
\cline { 2 - 4 } & LSCS & 26 & $9.25 \%$ \\
\cline { 2 - 4 } & NVD & 254 & $90.39 \%$ \\
\hline Abruption & 10 & $3.56 \%$ \\
\hline Eclampsia & 9 & $3.20 \%$ \\
\hline Magnesium Sulfphate & 33 & $11.74 \%$ \\
\hline HELLP & 4 & $1.42 \%$ \\
\hline DIC & 2 & $0.71 \%$ \\
\hline PE & 2 & $0.71 \%$ \\
\hline ARF & 2 & $0.71 \%$ \\
\hline Death & 1 & $0.36 \%$ \\
\hline Total & 281 & $100.00 \%$ \\
\hline
\end{tabular}

Table 2: Fetal complications at a glance

\begin{tabular}{|l|c|c|}
\hline \multicolumn{1}{|c|}{ Fetal complications } & Frequency & Percentage \\
\hline Fetal growth restriction & 20 & $28.9 \%$ \\
\hline Fetal distress & 6 & $8.69 \%$ \\
\hline Meconium stained liquor & 10 & $14.49 \%$ \\
\hline Intrauterine death & 3 & $4.34 \%$ \\
\hline Nicu Stay (causes) & 34 & $49.20 \%$ \\
& 16 & $47.05 \%$ \\
Prematurity & 2 & $5.88 \%$ \\
Meconium aspiration & 15 & $44.11 \%$ \\
syndrome & 1 & $2.94 \%$ \\
Fetal growth restriction & & $100.00 \%$ \\
Extremely low birth weight & 73 (Out of 281) \\
\hline Total & &
\end{tabular}

Table 3: Comparison of liver enzymes at inclusion and derangement

\begin{tabular}{|l|c|c|c|}
\hline & $\begin{array}{c}\text { At inclusion } \\
(\mathbf{n = 2 8 1})\end{array}$ & $\begin{array}{c}\text { P value } \\
\text { Derangement/Admission } \\
(\mathbf{n = 2 8 1})\end{array}$ & \\
\hline SGOT & & & \multirow{2}{*}{$<.0001$} \\
\hline Mean \pm Standard Deviation & $16.05 \pm 14.33$ & $31.25 \pm 28.27$ & \multirow{2}{*}{$<.0001$} \\
\hline SGPT & & & \multirow{2}{*}{$<.0001$} \\
\hline Mean \pm Standard Deviation & $17.6 \pm 15.84$ & $32.75 \pm 29.54$ & \\
\hline ALP & & & \\
\hline Mean \pm Standard Deviation & $208.62 \pm 32.06$ & $250.99 \pm 40.96$ & \\
\hline & & & \\
\hline
\end{tabular}


Table 4: Correlation between liver enzymes and blood pressure

\begin{tabular}{|c|c|c|c|c|}
\hline & & $\begin{array}{c}\text { SGOT at } \\
\text { Derangement } \\
\text { /admisssion }\end{array}$ & $\begin{array}{c}\text { SGPT at } \\
\text { Derangement } \\
\text { /admisssion }\end{array}$ & $\begin{array}{c}\text { ALP at } \\
\text { Derangement } \\
\text { /admisssion }\end{array}$ \\
\hline \multirow{3}{*}{$\begin{array}{l}\text { SBP at } \\
\text { Derangement } \\
\text { /admisssion }\end{array}$} & $\begin{array}{l}\text { Correlation } \\
\text { Coefficient }\end{array}$ & .56 & .568 & 0.193 \\
\hline & $\mathrm{P}$ value & $<.0001$ & $<.0001$ & 0.011 \\
\hline & $\mathrm{N}$ & 281 & 281 & 281 \\
\hline \multirow{3}{*}{$\begin{array}{l}\text { DBP at } \\
\text { Derangement } \\
\text { /admisssion }\end{array}$} & $\begin{array}{l}\text { Correlation } \\
\text { Coefficient }\end{array}$ & .573 & .558 & -0.03 \\
\hline & $\mathrm{P}$ value & $<.0001$ & $<.0001$ & .6116 \\
\hline & $\mathrm{N}$ & 281 & 281 & 281 \\
\hline
\end{tabular}

Table 5: Cut off value, sensitivity, specificity of liver enzymes for maternal complications

Maternal complications

\begin{tabular}{|l|c|c|c|c|c|c|c|c|c|}
\hline & AUC & $\begin{array}{c}\text { Standard } \\
\text { Error }\end{array}$ & $\begin{array}{c}\mathbf{9 5 \%} \text { Confidence } \\
\text { interval }\end{array}$ & P value & $\begin{array}{c}\text { Cut off } \\
\text { point }\end{array}$ & Sensitivity & Specificity & PPV & NPV \\
\hline $\begin{array}{l}\text { ALP at derangement } \\
\text { /admisssion }\end{array}$ & 0.545541 & 0.0499 & 0.485326 to 0.604786 & 0.361 & $>292$ & 32 & 87.45 & 35.557 & 85.597 \\
\hline $\begin{array}{l}\text { DBP at derangement } \\
\text { /admisssion }\end{array}$ & 0.907965 & 0.0281 & 0.867935 to 0.939072 & $<0.0001$ & $>96$ & 88 & 88.74 & 62.84 & 97.16 \\
\hline $\begin{array}{l}\text { SBP at derangement } \\
\text { /admisssion }\end{array}$ & 0.88013 & 0.0295 & 0.836306 to 0.915694 & $<0.0001$ & $>154$ & 74 & 91.77 & 66.05 & 94.22 \\
\hline $\begin{array}{l}\text { SGOT at } \\
\text { derangement } \\
\text { /admisssion }\end{array}$ & 0.913896 & 0.0221 & 0.874779 to 0.943943 & $<0.0001$ & $>66$ & 88 & 90.91 & 67.689 & 97.223 \\
\hline $\begin{array}{l}\text { SGPT at } \\
\text { derangement } \\
\text { /admisssion }\end{array}$ & 0.9129 & 0.0239 & 0.873627 to 0.943128 & $<0.0001$ & $>64$ & 88 & 90.04 & 65.65897. & 97.197 \\
\hline
\end{tabular}

At $66 \mathrm{IU} / \mathrm{L}$ aspartate aminotransferase is $88 \%$ specific and $90 \%$ sensitive for predicting maternal complications in epreeclamptic patients with deranged liver enzymes. Alanine aminotransferase at $64 \mathrm{IU} / \mathrm{L}$ is $88 \%$ sensitive and $90 \%$ specific for same. Hence an intervention at these levels can prevent fetomaternal morbidity.

Table 6: Cut off value, sensitivity, specificity of liver enzymes for fetal complications

Fetal Complications

\begin{tabular}{|l|c|c|c|c|c|c|c|c|c|}
\hline & AUC & $\begin{array}{c}\text { Standard } \\
\text { Error }\end{array}$ & $\begin{array}{c}\text { 95\% Confidence } \\
\text { interval }\end{array}$ & P value & $\begin{array}{c}\text { Cut } \\
\text { off } \\
\text { point }\end{array}$ & Sensitivity & Specificity & PPV & NPV \\
\hline $\begin{array}{l}\text { Alp at derangement } \\
\text { /admisssion }\end{array}$ & 0.564921 & 0.0497 & $\begin{array}{c}0.504748 \text { to } \\
0.623709\end{array}$ & 0.1913 & $>290$ & 33.96 & 86.84 & 37.49 & 84.98 \\
\hline $\begin{array}{l}\text { DBP at derangement } \\
\text { /admisssion }\end{array}$ & 0.9333 & 0.0233 & $\begin{array}{c}0.897508 \text { to } \\
0.959525\end{array}$ & $<0.0001$ & $>94$ & 94.34 & 89.47 & 67.56 & 98.55 \\
\hline $\begin{array}{l}\text { SBP at derangement } \\
\text { /admisssion }\end{array}$ & 0.924942 & 0.0184 & $\begin{array}{c}0.887649 \text { to } \\
0.952886\end{array}$ & $<0.0001$ & $>148$ & 94.34 & 84.21 & 58.14 & 98.46 \\
\hline $\begin{array}{l}\text { SGOT at } \\
\text { derangement } \\
\text { /admisssion }\end{array}$ & 0.940707 & 0.0187 & $\begin{array}{c}0.906347 \text { to } \\
0.965298\end{array}$ & $<0.0001$ & $>60$ & 94.34 & 92.54 & 74.61 & 98.6 \\
\hline $\begin{array}{l}\text { SGPT at } \\
\text { derangement } \\
\text { /admisssion }\end{array}$ & 0.938721 & 0.0203 & 0.903966 to & $<0.0001$ & $>64$ & 94.34 & 92.54 & 74.61 & 98.6 \\
\hline
\end{tabular}

At $60 \mathrm{IU} / \mathrm{L}$ aspartate aminotransferase is $94 \%$ sensitive and $92 \%$ specific for predicting fetal complications in preeclamptic patients with deranged liver enzymes. Alanine aminotransferase at $64 \mathrm{IU} / \mathrm{L}$ is $94 \%$ sensitive and $92 \%$ specific for same. Hence an intervention at these levels may be desirable for better fetomaternal outcome.

\section{Discussion}

Hypertensive disorders of pregnancy are one of the leading causes of maternal and perinatal morbidity and mortality. Value of liver function tests are rarely used as a cut off criteria for termination. In Indian context, not many studies have been done to evaluate maternal and neonatal outcome amongst pregnant women with 
preeclampsia with deranged liver enzymes and to correlate severity of liver enzymes derangement in preeclamptic mothers with adverse fetomaternal outcome. Various significant findings of my study are mentioned below with cut off.

In our study, 26 out of a total of 281 patients (9.25\%) underwent lower segment cesarean section. Out of these 26 patients, $76 \%$ patients were preeclamptic with deranged liver enzymes and $23 \%$ were preeclamptic with normal liver enzymes. Hence, LSCS were performed more in preeclamptic patients with deranged liver enzymes. Also 66\% patients with deranged liver enzymes had a normal vaginal delivery which was induced in $50 \%$ patients and spontaneous in the other 50\%. Aali BS et al ${ }^{16}$ Yucesoy $\mathrm{G}$ et $\mathrm{al}^{17}$ and Audibert $\mathrm{F}$ et al ${ }^{18}$ also reported results which are almost similar to our study and $\mathrm{P}$ value was noted to be significant.

Out of 69 patients with deranged liver enzymes, $47 \%$ required magnesium sulfate prophylaxis, $14 \%$ developed abruption, $13 \%$ developed eclampsia, 5.79\% went into HELLP Syndrome, 2.89\% developed DIC, $2.89 \%$ pulmonary edema, $0.35 \% \mathrm{ARF}$ and $0.35 \%$ died. As per Loi $\mathrm{K}$ et al $^{15}$ eclampsia (6\%), HELLP (6\%), Pulmonary edema (5\%), ARF (14\%), abruption (2\%) maternal complications were noted in preeclamptic patients with deranged liver enzymes.

As per Aali $\mathrm{BS}^{16}$ HELLP (5\%), pulmonary edema (3.6\%), ARF (5.4\%), Abruption (5.6\%) were noted in patients with complicated severe preeclampsia. A study by Yucesoy $\mathrm{G}$ et al ${ }^{17}$ noted eclampsia (11\%), abruption $(1.5 \%)$ and maternal mortality in $3 \%$ patients. Studies by Haddad B, ${ }^{9}$ Wodeselsassie, ${ }^{20}$ Menezies et al, ${ }^{21}$ Kozic et $\mathrm{al}^{22}$ support these results.

Out of 69 preeclamptic patients with deranged liver enzymes, $28.90 \%$ developed FGR, $8.69 \%$ developed FD, $14.49 \%$ MSL, 4.34\% IUD, $49.20 \%$ NICU stay because of Prematurity in $47.05 \%$ babies, MAS in $5.88 \%$, FGR in $44.11 \%$ and ELBW in $2.94 \%$ neonates. Aali $\mathrm{BS}^{16}$ noted $47 \%$ premature births, 6\% IUD and LBW in $34 \%$ preeclamptic patients with deranged liver enzymes.

Yucesoy $\mathrm{G}$ et $\mathrm{al}^{17}$ noted FGR in $29.4 \%$ and LBW in $34 \%$ preeclamptic patients with elevated liver enzymes. Verhaeghe et $\mathrm{al}^{23}$ Menezies et $\mathrm{al}^{21}$ and Abramovici et $\mathrm{al}^{24}$ noted similar results as our study

SGOT at derangement had a cut off value $66 \mathrm{IU} / \mathrm{L}$ with sensitivity of $88 \%$, specificity $90 \%$ for maternal complications, $\mathrm{P}$ value was significant for same $<0.0001$. SGPT at derangement had a cut off value 64 IU/L with sensitivity of $88 \%$, specificity $90 \%$ for maternal complications and $\mathrm{P}$ value was significant $<0.0001$.

SGOT at derangement had a cut off value $60 \mathrm{IU} / \mathrm{L}$ with sensitivity of $94 \%$ and specificity $92 \%$ for fetal complications with a significant $\mathrm{p}$ value. SGPT at derangement had a cut off value $64 \mathrm{IU} / \mathrm{L}$ with sensitivity of $94 \%$, specificity $92 \%$ for fetal complications with $\mathrm{P}$ value being significant $<0.0001$.

A study by Haddad $\mathrm{B}^{19}$ calculated ALT/AST values as 70/70 as a cut off, Wodeselsassie ${ }^{20}$ calculated ALT /AST as 60/43, Menezies et $\mathrm{al}^{21}$ calculated ALT/AST as 40/55 and Audibert $\mathrm{F}$ et $\mathrm{al}^{18}$ calculated ALT/AST as $70 / 70$ as a cut off for liver function tests which are similar to our study.

In the preeclampsia patients under study, $81 \%$ with deranged liver enzymes landed up with a premature delivery as a strategic intervention. $28 \%$ babies were admitted to neonatal intensive care unit and $72 \%$ were shifted motherside. Out of the admitted, $94.75 \%$ were discharged after 2-3 day NICU stay and some continued. Three babies expired due to respiratory distress syndrome. At one month follow up of the babies, all were healthy and doing well. Gladstone $\mathrm{M}$ et $\mathrm{al}^{26}{ }^{26}$ Engmann et $\mathrm{al}^{25}$ reported neonatal mortality rate in premature babies between 1.6-7.3\% which are almost similar to our study. Above findings support that early intervention although increases the prematurity rate but outcome of such premature babies is satisfactory and one month follow up also reveals that all babies are doing well who would have otherwise landed up as an IUD or developed more fetal complications than noted in our study.

\section{Conclusion}

From the present study it can be concluded that severity of liver function test derangement is directly related to severity of preeclampsia which in turn is related to severity of fetomaternal complications.

These complications were noted in the form of severe. Preeclampsia, impending eclampsia, eclampsia, HELLP syndrome, placental abruption, intensive care unit stay, liver failure, renal failure, hepatic encephalopathy, post partum haemorrhage. Fetal complications were noted in the form of meconium stain, fetal growth restriction, fetal distress, intrauterine death and neonatal intensive care unit stay of the baby

From the present study it can be derived that at AST $>66 \mathrm{IU} / \mathrm{L}$ and ALT $>64 \mathrm{IU} / \mathrm{L}$ poor maternal outcome is expected. With AST $>60$ IU/L and ALT>64 IU/L adverse fetal complications are likely to occur.

\section{Acknowledgement}

I would like to thank Dr. G. Rammurthy, Department of Obstetrics and Gynaecology, BSAH, Delhi for helping and giving guidance in making this paper.

\section{References}

1. Martin J, Hamilton B,Ventura S et al. Births: final data for 2001.USA:National vital statistics; 2002.

2. Berg CJ, Chang J, Callaghan WM and Whitehead SJ, "Pregnancy related Mortality in the United States, 19911997', Obstetrics and Gynecology, 2003; vol.101, no.2, pp. 289-296. 
3. Hauth JC, Ewell M.G, Levine R.J. et al. "Pregnancy outcomes in healthy nulliparas who developed hypertension," Obstetrics and Gynaecology, 2000;vol.95,no.1, pp. 24-28.

4. Vatten LJ and R. Skjaeven, "Is preeclampsia more than one disease?" BJOG, 2004; vol.111, no.4, pp. 298-302.

5. The American Journal of Gastroenterology. Liver disease in pregnant patient. Practice Bulletin.1999;94.

6. Clapp JF $3^{\text {rd }}$, Stepanchak W, Tomaselli J, Kortan M, Faneslaw S. Portal vein blood flow-effects of pregnancy, gravity and exercise. Am J Obstet Gynecol 2000;183(1):167-72.

7. Combes B, Adams RH. Disorder of the liver in pregnancy: Pathophysiology of gestation.Vol.1. New York; 1971.

8. Bacq Y, Zarka O, Brechot JF, Marionette N, Vol S, Lichet $\mathrm{J}$ et al. Liver function tests in normal pregnancy: a prospective study of 103 pregnant women and 103 matched controls. Hepatology 1996;23(5):1030-4.

9. Larsson A, Palm M, Hansson LO, Axelsson O. Reference values for clinical chemistry tests during normal pregnancy. BJOG 2008;115(7):874-81.

10. Lockitch G. Handbook of diagnostic biochemistry and haematology in normal pregnancy. Boca Raton: CRC press; 1993 .

11. Van Buul, EJ, Steegers EA, Jongsma HW, Eskes TK, Thomas CM, Hein PR. Hematological and biochemical profile of uncomplicated pregnancy in nulliparous women: a longitudinal study. Neth J Med 1995;46(2):7385.

12. Disorders of the liver, biliary system and pancreas. De swiet's medical disorders in obstetric practice, $4^{\text {th }}$ edition; pp. 283.chapter 9 .

13. Hepatic and gastrointestinal disease. James' high risk pregnancy management options, 3rd edition; pp1033.chapter 48 .

14. The management of hypertensive disorders during pregnancy. National Institute for health and Clinical Excellence 2010.

15. Loi K, Khoo, CK, Jan KH, Yeo GS, Kwek K.A review of 93 cases of severe preeclampsia in Singapore: are there risk factors for complications? Singapore Med. J.2007;48(9):808-12.

16. Aali BS, Ghafoorian J, Mohamad-Alizadeh S. Severe preeclampsia and eclampsia in Kerman, Iran: complications and outcomes. Med Sci Monit. 2004 Apr;10(4):CR163-7.

17. Yücesoy G, Ozkan S, Bodur H, Tan T, Calişkan E, Vural B. Maternal and perinatal outcome in pregnancies complicated with hypertensive disorder of pregnancy: a seven year experience of a tertiary care center. Arch Gynecol Obstet. 2005 Nov;273(1):43-9.

18. Audibert F, Friedman SA, Frangieh AY, Sibai BM. Clinical Utility of Strict Diagnostic Criteria for the HELLP (Hemolysis, Elevated Liver Enzymes, and Low Platelets) Syndrome. AJOG 1996;175:460-464.

19. Haddad B, Barton JR, Livingston JC, Chahine R, Sibai BM.HELLP (hemolysis, elevated liver enzymes, and low platelet count) syndrome versus severe preeclampsia: onset at $<28.0$ weeks' gestation. Am J Obstet Gynecol. 2000 Dec;183(6):1475-9.

20. Woldeselassie. Master in public health; 2005.

21. Menzies J, Magee LA, Li J, MacNab YC, Yin R, Stuart H et al. Instituting surveillance guidelines and adverse outcomes in preeclampsia. Obstet Gynecol 2007 July;110(1):121-7.

22. Kozic JR, Benton SJ, Hutcheon JA, Payne BA, Magie LA. Abnormal liver function tests as predictors of adverse maternal outcomes in women with preeclampsia. Journal of Obstetrics and Gynecology Canada.2011;33(10):995-1004.

23. Vergaeghe J, Anthony J, Dave DA. Platelet count and liver function tests in proteinuric and chronic hypertension in pregnancy. S Afr Med 1991;79(10):5904.

24. Abramovici D, Friedman SA, Mercer BM, Audibert F, Kao L, Sibai BM. Neonatal outcome in severe preeclampsia at 24 to 36 weeks' gestation: Does the HELLP (hemolysis, elevated liver enzymes, and low platelet count) syndrome matter? Am J Obstet Gynecol.1999 Jan;180:221-5.

25. Engmann C, Walega P, Aborigo RA, Adongo P, Moyer $\mathrm{CA}$ et al.Stillbirths and early neonatal mortality in rural northern ghana. Trop Med Int Health. 2012 Mar;17(3):272-82.

26. Gladstone M, Oliver C, Van den Broek N. Survival, Morbidity, Growth and Developmental Delay for Babies Born Preterm in Low and Middle Income Countries. A Systematic Review of Outcomes Measured. Plos One 2015;10(3). 